Journal of Engineering Sciences, Assiut University, Vol. 37, No. 2, pp. 413-422, March 2009.

\title{
POTENTIAL USE OF PHOSPHATE WASTES AS AGGREGATES IN ROAD CONSTRUCTION
}

\author{
A. A. AHMED and A. Z. M. ABOUZEID \\ ${ }^{a}$ Assiut Univ., Faculty of Engineering, Dept. of Mining \& Metallurgy, \\ Assiut 71516, Egypt \\ ${ }^{b}$ Cairo Univ., Faculty of Engineering, Dept. of Mining, Giza 12613 , \\ Egypt
}

(Received February 4, 2009 Accepted February 19, 2009)

\begin{abstract}
Large quantities of solid wastes are generated in El-Nassar Mining Company at Sebaeya, Egypt as a result of mineral processing of phosphate ores. Over the years, the majority of these wastes have been stored in dumping areas which is aesthetically unattractive and degrading to the environment. However, these wastes, because of their similarity to conventional soils and aggregates, represent potentially useful sources of material for a variety of applications.

This paper is concerned with investigating the suitability of the coarse solid wastes generated from upgrading sebaeya phosphate ores as aggregates for road paving. The properties of these wastes are tested, according to the Egyptian Standard Test Methods for road constructions. The obtained results proved that this kind of wastes can be used in road construction. The positive uses of these wastes are considered beneficial from the economic and environmental point of view.
\end{abstract}

KEYWORDS: Phosphate, waste utilization, road construction, aggregates, environmental cleaning

\section{INTRODUCTION}

As high-grade Phosphate deposits are mostly depleted, the importance of low-grade deposits increases. Consequently, large quantities of solid wastes(about 1.5 million ton) are generated and accumulated as a result of processing these low-grade ores. Disposal of these wastes is becoming an acute environmental issue in addition to the added cost for their removal [1]. Waste utilization is an attractive alternative solution to the disposal of the solid wastes. This positive alternative saves disposal costs, reduces pollution problems, and conserves natural resources [2-3]. Most mineral wastes have limited potential for reuse because of their high impurity content or remote location. The mining industry has traditionally made use of its own waste materials, either by reprocessing to recover additional values, local construction purposes, or for land refill [3-4].

The basic mineral processing techniques involved in the milling and concentration of phosphate ores are crushing, screening, washing, classification, flotation and/or magnetic separation. As a result of preparation and beneficiation, two kinds of waste product are formed; coarse mill rejects from screening and fine mill tailings from washing and separation [4]. 
The quality of mineral processing of wastes varies widely and is highly dependent on the specific source. When the location and material property conditions are favorable, some sources of waste rock or coarse mill tailings may be suitable for use as granular base /sub-base, railroad ballast, aggregate in concrete and asphalt mixes [4-13]. Fine mill tailings, can be used as construction sand, an additive to concrete and asphalt mixes, in brick and block manufacture, in the manufacture of thermal insulation, for recovery of valuable minerals and in ceramic and pottery making [6-14] .

Road construction today consists, generally, of four layers of aggregates as shown in Fig.1. These layers collectively are termed "the pavement". The type of aggregates and thickness of each layer depend on the type of the road and the use for which it is designed. The behavior of all layers is crucial to the stability and safety of the road [10-11].

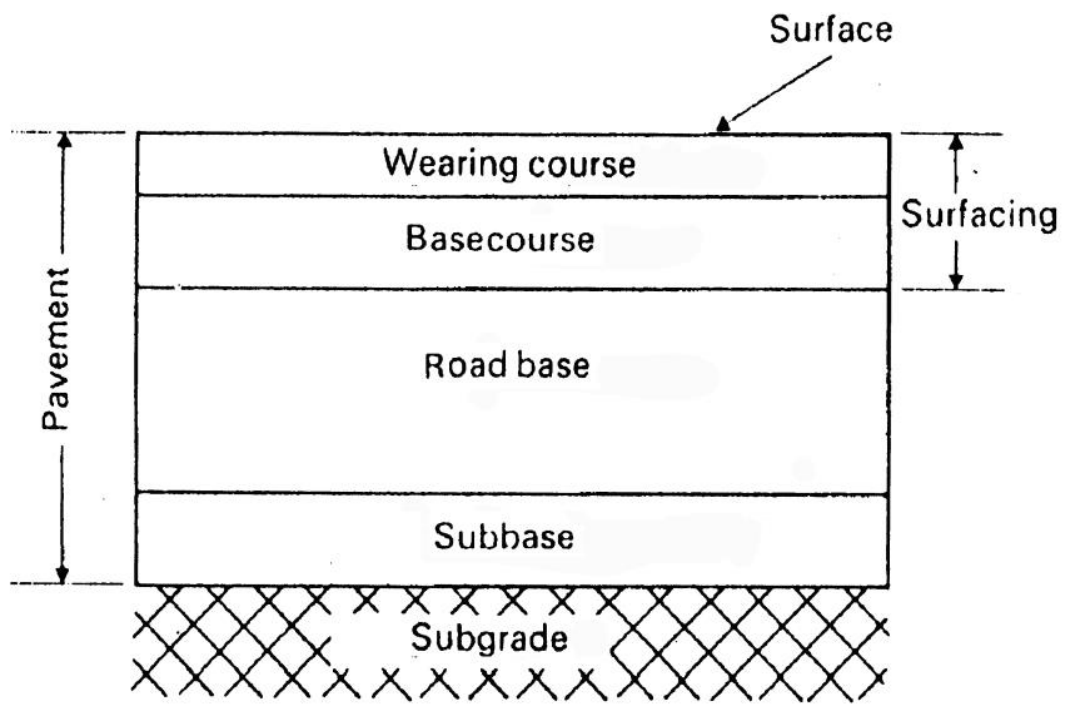

Figure 1: Structural layers in road construction [11].

Unbound granular materials of mill wastes are generally used in road construction applications as base / sub-base courses, which are important components of roads as surface composition and foundations [10-11]. As a base course, they play structurally important role, especially on medium and low volume roads. As a sub-base, they protect the soil, and act as working platform and an insulating layer against frost action. The favorite use of these solid wastes can be used locally in low-volume roads, where a lower quality aggregate is more appropriate [10]. The properties of road aggregates differ from road to another according to the road category. The main properties of aggregates are gradation, particle shape and texture, deleterious substances (clay and other contaminants), hardness (or resistance to wear), durability, crushing strength and compaction properties (maximum dry density and optimum water content) [6,10,11].

At Sebaeya, there are large accumulations of waste material produced from the phosphate milling plant [1]. As a result of benefication a coarse waste ( over screen rejects ) and fine tailings ( e.g., clays, silica sand, dolomite, etc.) were 
generated from the washing plant. The accumulation of solid wastes constitutes environmental problems and must be removed. The main objective of this investigation is to evaluate the possibility of using solid wastes generated from the beneficiation of Sebaeya phosphate in road construction as base or sub-base aggregates. The substantial benefits of using these waste materials for road building purposes can be summarized in the reduction of costs, and solution of the environmental problems.

\section{EXPERIMENTAL WORK}

\section{Material}

Head sample of $200 \mathrm{~kg}$ solid wastes (over screen reject) was obtained from Sebaeya phosphate dump. The sample is thoroughly mixed and divided by coning \& quartering into two portions, one for road paving tests and the other was kept to be used for the other purposes. The portion of the sample used in this investigation was crushed to pass $40 \mathrm{~mm}$ (the maximum size for road base/sub-base construction). The head sample assay was $21.65 \% \mathrm{SiO}_{2}, 42.95 \% \mathrm{CaO}, 0.40 \% \mathrm{Na}_{2} \mathrm{O}$, $0.03 \% \mathrm{~K}_{2} \mathrm{O}$ and $8.74 \%$ L.O.I.

\section{Procedures}

The most important aggregate quality tests are:

1- Physical properties: such as particle shape, texture, true density, bulk density, water adsorption and deleterious substances. Details of the test procedure are given in reference $[11,15]$.

2- Gradation (Grain size analysis): The purpose of this test is to obtain a specific grain size distribution of the aggregates. The standard set of screen used in aggregate gradation are : $2.0 \mathrm{inch}, 1.5 \mathrm{inch}, 1.0 \mathrm{inch}, 3 / 4 \mathrm{inch}, 3 / 8$ inch, 4 mesh $(4.75 \mathrm{~mm}), 10$ mesh ( $2.0 \mathrm{~mm}), 40$ mesh $(0.425 \mathrm{~mm})$, and 200 mesh $(0.075 \mathrm{~mm})$. The test procedure is given elsewhere $[11,15,16]$.

3- The standard compaction test: (compacted density and moisture adsorption): This test also known as the moisture-density test. It measures the maximum dry density that aggregates can reach under a specified compaction stress, and amount of water adsorbed at maximum dry compacted density. The apparatus used consists of standard compaction mold, standard compaction hammer, balance, and dry oven as shown in Fig. 2. The procedure is given in details elsewhere [11].

4- California Bearing Ratio (C B R): The California Bearing Ratio test is one of the common methods to evaluate the strength of sub-grade quality aggregates for pavement design [11].

The procedure of the test is given in details in references [16-17], and the apparatus is shown in Fig. 2.

5- Los Angeles Abrasion test: This test is an accepted measure of the hardness of coarse aggregates $(-38+2.0 \mathrm{~mm}$ size). Figure 3 shows the Los Angeles apparatus and the procedure of the test is given in detail in references [11, $16]$. 


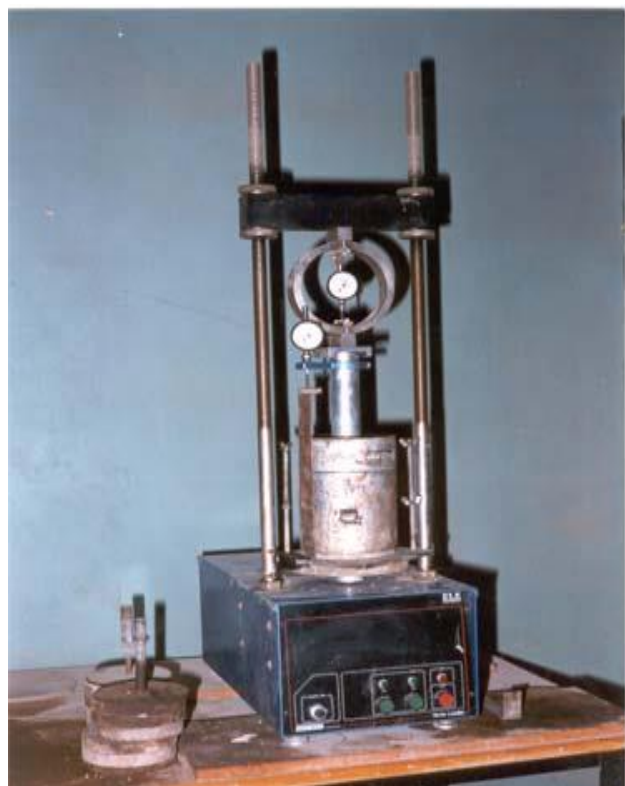

(2 a)

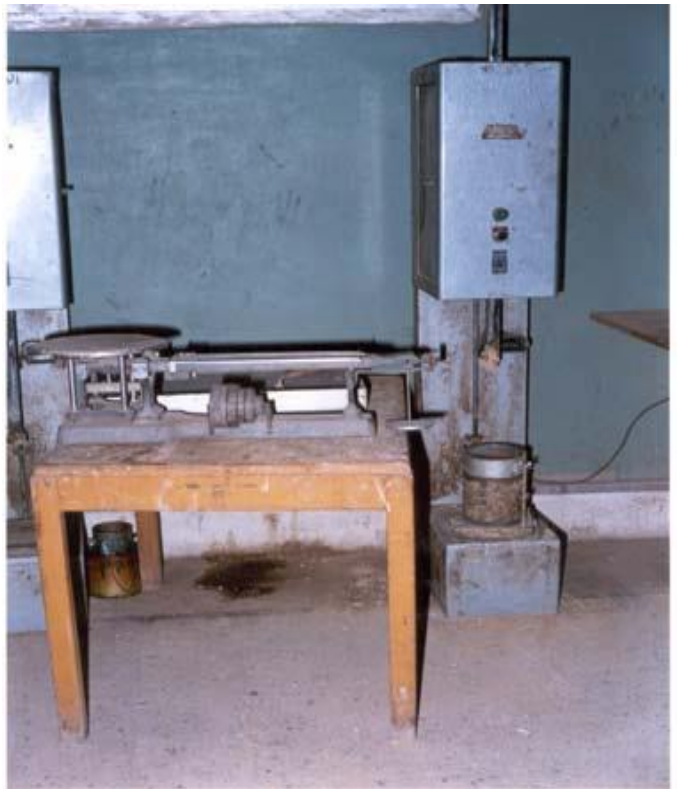

(2 b)

Figure 2: (a) California Bearing Ratio (CBR), (b) Standard compaction test (proctor's test).

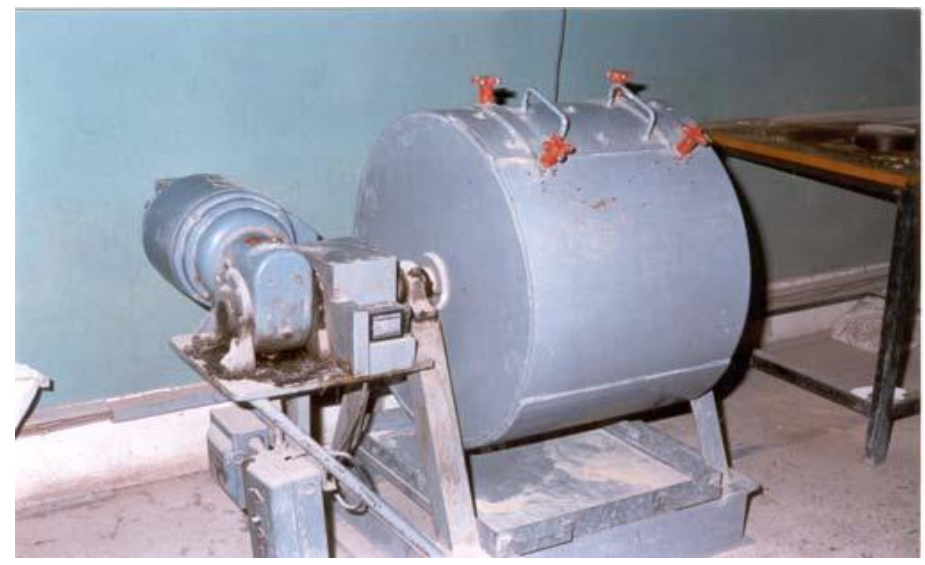

Figure 3: Los Angeles abrasion apparatus

6- Slake Durability test: It measures the aggregates durability (resistance to weathering) expressed in Id2 values. When these values approach zero for a sample, this means that the sample is highly susceptible to slaking, and when they approach $100 \%$, this means that this material is a rocklike material that is slightly slaking. The apparatus used is shown in Fig. 4, and the procedure of the test is given in details in references [17].

7- Crushing strength test: The aggregates used in the base and sub-base for road construction should be hard to resist grinding action, and strong to withstand heavy loads. The crushing strength of coarse aggregates is 
expressed as the "Aggregate crushing value" which is the percentage of minus $2.5 \mathrm{~mm}$ material in the crushed load. Fig. 5 shows the apparatus used for this purpose and its schematic drawing in action. The procedure of the test is given in details in references $[11,16]$.

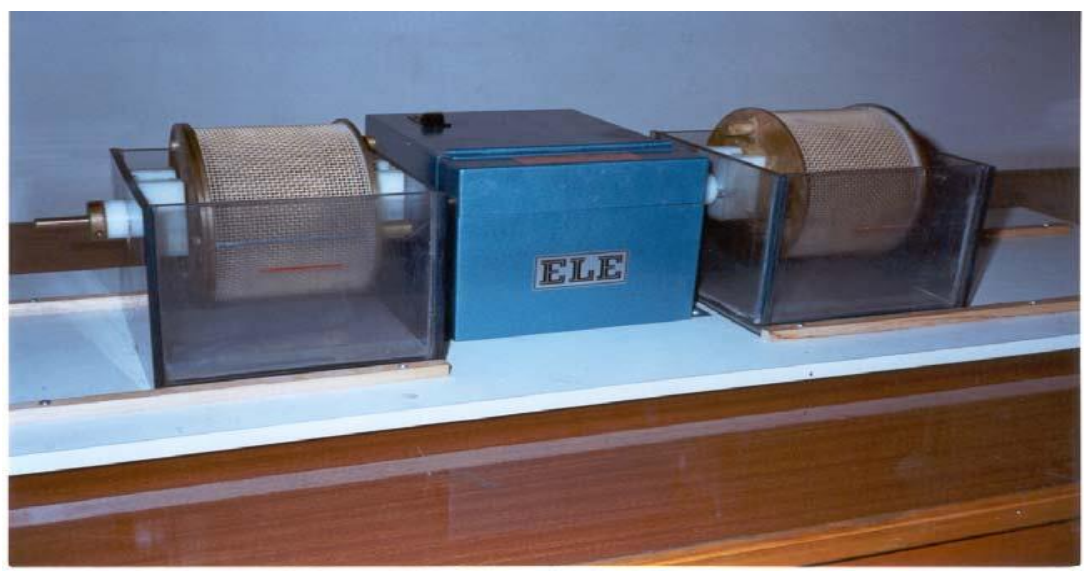

Figure 4 : Slake durability test apparatus

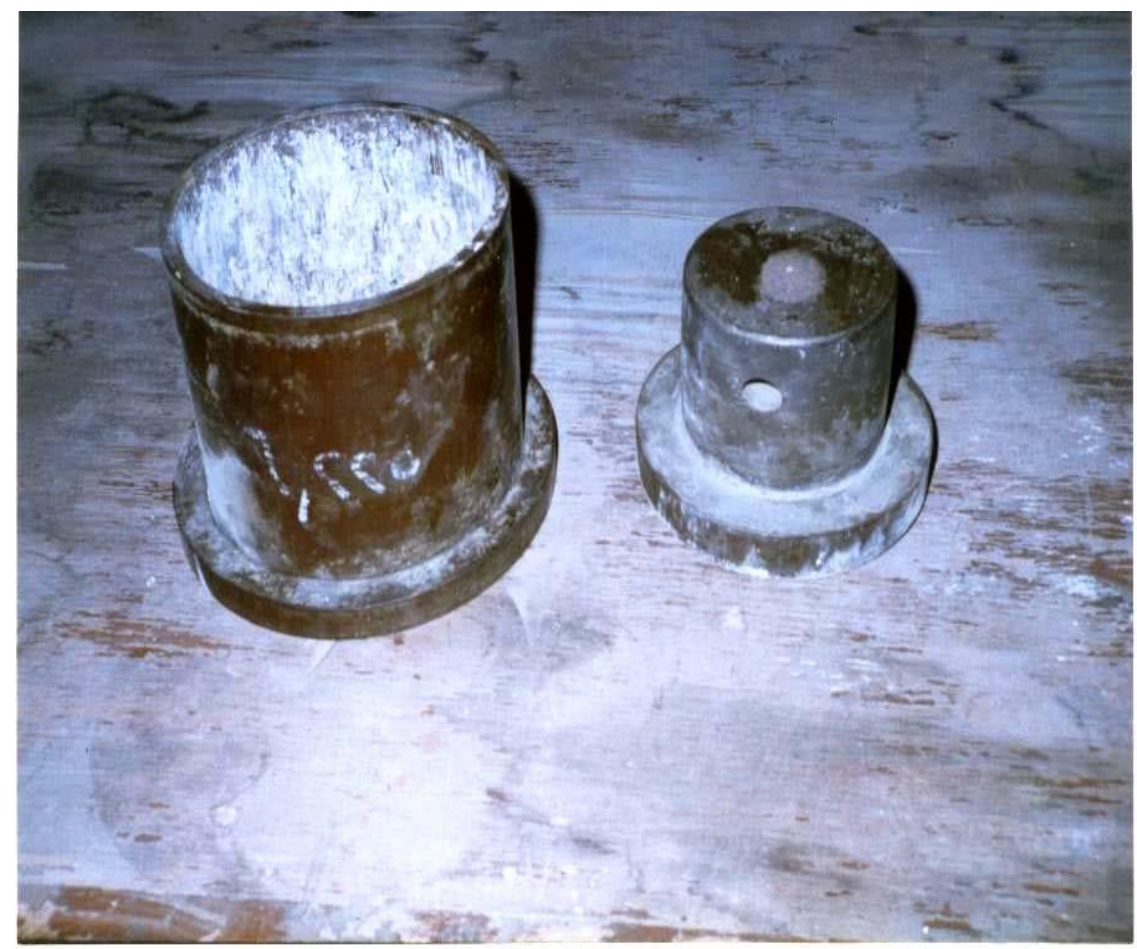




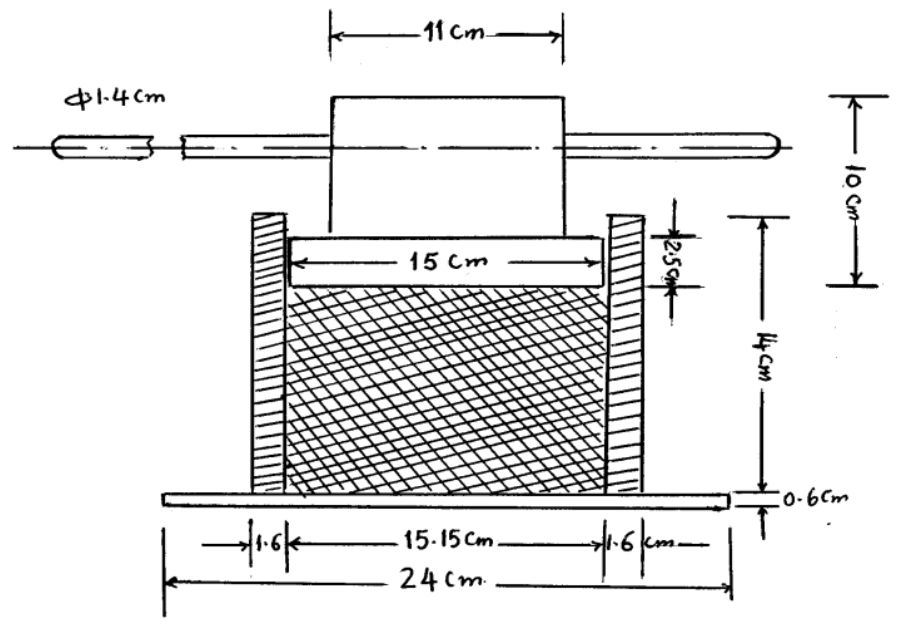

(5b)

Figure $5(\mathrm{a} \& \mathrm{~b})$ : The Two Parts of crushing strength apparatus

\section{RESULTS AND DISCUSSION}

The required specifications of aggregates depend on the purpose in which they will be used. There are no standard specifications for mill waste materials as aggregates in granular base or sub-base of road construction. The aggregates must meet size requirements; satisfy standard Proctor moisture-density criteria and a minimum durability value, in addition to restricted physical and chemical properties. Tables 1 through 4 states the various test values as measured for the Sebaeya phosphate coarse aggregates. These values are compared with the corresponding standard values in the same tables.

1- Physical and chemical properties: The measured as well as the standard values of each property, whenever there is a corresponding standard value, are shown in Table 1.

Table 1: Physical and chemical properties of Sebaeya phosphate aggregates.

The standard values are taken from references 4, 9, 11, and 15 .

\begin{tabular}{|l|c|c|}
\hline Property & Measured values & Standard values \\
\hline Particle shape & Irregular & - \\
\hline Surface texture & Rough & - \\
\hline True density, g/cm ${ }^{3}$ & 2.655 & $2.0-2.3$ \\
\hline Bulk density , g/cm ${ }^{3}$ & 1.4 & - \\
\hline Water adsorption, wt.\% & 6.0 & $<10$ \\
\hline Deleterious substances, wt.\% & 1.51 & $<3$ \\
\hline Chlorine ion, wt \% & 0.0238 & $<0.04$ \\
\hline Sulfate ion, wt. \% & 0.0709 & $<0.4$ \\
\hline pH & 7.60 & Alkaline \\
\hline
\end{tabular}


Table 2-a: Gradation of aggregates used in road construction, measured and standard values [15].

\begin{tabular}{|l|c|c|c|c|}
\hline Size range & \multicolumn{2}{|c|}{ Measured distribution } & \multicolumn{2}{l|}{ Standard distribution } \\
\cline { 2 - 5 } & $\begin{array}{c}\text { Frequency } \\
\text { wt } \%\end{array}$ & $\begin{array}{c}\text { Cum. } \\
\text { Pass, wt } \\
\%\end{array}$ & $\begin{array}{c}\text { Frequency }, \\
\text { wt \% }\end{array}$ & $\begin{array}{c}\text { Cum. } \\
\text { Pass, wt \% }\end{array}$ \\
\hline 1.5 in+1.0 in & 6 & 100 & 15 & 100 \\
\hline 1.0 in+ 3/4 in & 11 & 94 & 10 & $70-100(85)^{*}$ \\
\hline $3 / 4$ in $+3 / 8$ in & 33 & 83 & 15 & $60-90(75)$ \\
\hline $3 / 8$ in +4 mesh & 34 & 50 & 15 & $45-75(60)$ \\
\hline 4 mesh +10 mesh & 7 & 16 & 10 & $30-60(45)$ \\
\hline 10 mesh +40 mesh & 2 & 9 & 15 & $20-50(35)$ \\
\hline 40 mesh +200 mesh & 2 & 7 & 12.5 & $10-30(25)$ \\
\hline 200 mesh & 5 & 5 & 7.5 & $5-15(7.5)$ \\
\hline
\end{tabular}

* Average values for the size fractions in the standard values.

All the measured values for the phosphate waste aggregates are within the standard values as stated in the literature [15].

2- Gradation: One of the important specifications of the road construction materials is the size distribution of the aggregates. Table 2-a presents the gradation of Sebaeya phosphate aggregates and the corresponding standard distribution of the road construction materials.

From Table 2-a, there is disagreement between some of the measured values and the standard ones. The size fractions can be grouped into 3 groups as shown in Table 2-b.

Table 2-b: Size fractions combined into three groups (measured \& standard).

\begin{tabular}{|l|c|c|}
\hline Size fractions & $\begin{array}{c}\text { Measured frequency, } \\
\text { wt. } \%\end{array}$ & Standard frequency, wt.\% \\
\hline 1.5 in $+3 / 4$ in & 17 & 25 \\
\hline $3 / 4$ in +4 mesh & 67 & 30 \\
\hline 4 mesh & 16 & 45 \\
\hline
\end{tabular}

In this case, the mismatch can be corrected simply by crushing $50 \%$ of the fraction $-3 / 4$ inch +4 mesh to pass 4 mesh screen. This will reduce the $-3 / 4$ in +4 mesh to about $33 \%$ (the standard value is on the average $30 \%$ ), and increase the minus 4 mesh to about $50 \%$ of the total sample weight (the standard minus 4 mesh is on the average $45 \%$ ). This operation makes the measured values match the standard values. 3- Relative dry density, water adsorption and California Bearing Ratio (CBR) are tested by carrying out the standard compaction test on the solid aggregates. The obtained results as well as the Egyptian standard values are given in Table 3. 
Table 3: Relative density, CBR, Los Angeles, and Slake Durability results of solid wastes for road construction.

\begin{tabular}{|l|c|c|}
\hline \multicolumn{1}{|c|}{ Test } & Measured Values & $\begin{array}{c}\text { Standard } \\
\text { Values* }\end{array}$ \\
\hline Dry density, g/cm & & $1.6-2.025$ \\
\hline Water adsorption, \% & 1.95 & $10-18$ \\
\hline CBR $\%$ & 13 & $<25$ \\
\hline Los Angels Values, \% & 69.7 & $<50$ \\
\hline Slake Durability, id2\% & 45.2 & Approach 100 \\
\hline
\end{tabular}

* References $[9,10,15,17]$

4- Crushing strength: The crushing strength test results for three replicates carried out for evaluating the crushing strength of Sebaeya phosphate waste aggregates are given in Table 4.

Table 4 : crushing strength test results for Sebaeya phosphate aggregates.

\begin{tabular}{|l|c|c|c|}
\hline \multicolumn{1}{|c|}{ Item } & Test 1 & Test 2 & Test 3 \\
\hline Weight of empty mortar, g & 6225 & 6225 & 6225 \\
\hline Weight of compacted mortar, g & 9480 & 9420 & 9370 \\
\hline Net Weight of aggregate, g & 3255 & 3195 & 3145 \\
\hline Weight of crushed ore (- 2.5 mm ),g & 950 & 965 & 900 \\
\hline Crushing strength , \% & 29.18 & 30.2 & 28.62 \\
\hline Average measured crushing strength, \% & \multicolumn{3}{|c|}{ Not more than 30 } \\
\hline Standard crushing strength, \% & \multicolumn{3}{|c}{} \\
\hline
\end{tabular}

The average crushing strength percent for the three replicates is reproducible. The average measured value of the crushing strength percent is $29.3 \%$, which is within the limits of the standard value.

From tables 1 through 4 , it is clear that, the quality of phosphate wastes aggregates, as over screen reject from Sebaeya beneficiation plant, matches the Egyptian standard specification of natural materials used in road construction.

\section{SUMMARY AND CONCLUSIONS}

The obtained results in this research work, as correlated with the standard values, can be summarized as follows:

1- The properties ( physical, chemical and mechanical) of coarse phosphate waste aggregates from Sebaeya phosphate beneficiation plant are similar to those of conventional mineral aggregates used in road construction and water-bound macadam roads ( WBM ). 
2- The deviation of the size grading of the used sample from the standard specifications can be corrected by crushing part of the $-3 / 4$ inch +4 mesh size fraction.

3- The produced aggregates can be safely used in the construction of local low volume roads.

4- The use of solid wastes as aggregates in road construction can be a positive solution to remedy the environmental problems created by dumping these wastes in the open area surrounding the plant. This is an urgent demand for the surrounding society. In addition, the cost per ton of phosphate product will be reduced by omitting the transportation cost of the waste material.

5- Saving in cost of material used for road construction ( i.e. no mining, crushing and transportation costs ) are required. In addition, it conserves the natural resources that could have, otherwise, been use for road construction.

\section{REFERENCES}

1- Negm, A.A. and Abouzeid, A-Z.M.: "Utilization of solid wastes from phosphate processing plants", Physico chemical problems of Mineral Processing, Poland, Vol.42, pp.5-16, (2008).

2- Hanna, S. and Rampacek,C.: "Resources potential of mineral and metallurgical wastes", Proceedings of Inter. Symp. of Fine particles processing, Edited by Samasundaran , P. , Vol. 2 , pp. 1731-1753, Lasvegas, Nevada , 24-28 feb.,(1980).

3- Collings, R.K. and Miller, R.H.: "Utilization of mining and mineral processing wastes in the united states", Minerals and the Environment, Vol.1, No.1, pp.8-19, April (1979).

4- Collings, R.K.: "Current and potential uses for mining and mineral processing wastes in Canada: Standards," J. of Testing and Evaluation, Vol.12, No.1, pp. 46-50, Jan . (1984).

5- El-Wageeh, M.A.: "Mining environmental management", ${ }^{\text {st }}$ Inter. Conf., The Environmental and Development in Africa, Assiut Univ., pp.316-327, 2124 Oct. (1995)

6- Down, C.G. and Stocks, J.: "Positive uses of mill tailings," Mining Magazine, pp.213-223, Sept. (1977).

7- Timberlake, R.C.: "Building land with phosphate wastes," Mining Engineering, pp.38-40, Dec. (1969).

8- Himida, M.M.: "A study on the possibility of utilizing phosphate mill tailing of some Egyptian phosphate mines" , M. Sc. Thesis , Faculty of Engineering, Assiut Univ., Assiut, Egypt, ( 1999).

9- "Mineral processing wastes: User guideline and Material description" Internet communication, (2005).

10- "Unbound granular materials for road pavement," Intemet communication, pp.1-3, (2003).

11- Atkins, H.A.: "High way materials, soils and concretes," second edition, Reston Publishing Company, Inc., Reston, Virginia, pp 116-163, (1993).

12- Emery, J.J.: "Use of mining and metallurgical waste in construction," 
Minerals and Environment, paper No.18, London, England, June (1974).

13- Kirkendal , G.A.: "A text book for ceramic engineers," Edwards Brothers , Inc., Michigan, U.S.A.,pp.1-5 , ( 1960 ).

14- Maslova, M., Gerasimova, L., Shcherbakova, E. and Abramov, A.: "Utilization of mineral wastes of apatite production," Rewas'04-Global Symposium on Recycling, Waste Treatment and Clean Technology, pp.29452947, (2005).

15- Egyptian standards of Road Construction, Fourth Part, "Transportation materials and methods for Testing materials," No. 160, (1998) in Arabic.

16- Vazirani, V.N.and Chandola, S.P.: "High way and soil engineering," Khanna publishers, 2-B Nath. Market, Nai Sarak Delhi-110006, First edition, pp.150-159, (1978).

17- Franklin, J.A.and Dusseault.B.M.: "Rock Engineering," McGraw Hill Publishing Company, Tokyo, pp.43-46, (1989).

18- Yoder, E.J: "Principles of pavement design," John Wiley \& Sons, INC., London, pp.283-301, (1959).

19- Basu, A.K. and Bhattacharjee, P.K.: "Text book of road Engineering," Orient Longmans, Bombay calcutta Madras, New Delhi, pp.118-126, (1966)

\section{الاستخدام الإيجابي لنفايات الفوسفات كركام في تأسيس الطرق}

تتراكم كميات كبيرة من النفايات الصلبة ناتج مرحلة الغربلة لعملية نركيز خام الفوسفات بمنطقة السباعية شرق. وتشون هذه النفايات في أكوام في مناطق قربية من مصنع تركيز الفوسفات والتي بدورها تؤدى إلى لى

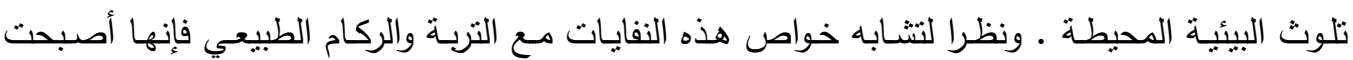
مصدرا للاستخدام في كثير من التطبيقات . ماته

وفى هذا البحث ثم التركيز على دراسة ملائمة النفايات الصلبة الناجمة من عملية الغربلة كركام يصلح في تأسيس الطـرق البربـة المحيطـة بمنطقة العمل.وقد تم دراسـة واختبـار خـواص هذه النفايـات طبقا للمواصفات المصرية القياسية في تتفيذ الطرق البرية والخلوية. ومن النتائج المعملية تأكد مدى ملائمـة هذه النفايات للاستخدام كركام في تأسيس الطرق البرية والخلوية وخاصـة بمناطق التعدين . والاستخدام الإيجابي لهذه النفايات يعتبر مفيد من حيث كونها تقلل من الاعتماد على المصادر الطبيعية للركام وتحد من المخاطر البيئية الناجمة عن ثراكمها ـ 